\title{
SINTESIS KRISTAL TUNGGAL PEROVSKITE MAPbBr 3 MENGGUNAKAN METODE INVERSE TEMPERATURE CRYSTALLIZATION UNTUK APLIKASI FOTODETEKTOR SINAR-X
}

\author{
ROSSYAILA MATSNA MUSLIMAWATI ${ }^{1}$, AYI BAHTIAR ${ }^{2}$ * \\ ${ }^{1}$ Program Studi S2 Fisika, FMIPA, Universitas Padjadjaran \\ Jl. Raya Bandung-Sumedang Km.21 Jatinangor 45363, Sumedang, Jawa Barat \\ ${ }^{2}$ Departemen Fisika, FMIPA, Universitas Padjadjaran \\ Jl. Raya Bandung-Sumedang Km.21 Jatinangor 45363, Sumedang, Jawa Barat
}

*email : ayi.bahtiar@phys.unpad.ac.id

\begin{abstract}
Abstrak. Metilamonium timbal tri-bromid $\left(\mathrm{MAPbBr}_{3}\right)$ merupakan material perovskite logam halida yang umum untuk digunakan untuk aplikasi fotodetektor sinar-X. Namun, jika perovskite berstruktur polikristal maka resistivitasnya tinggi. Oleh sebab itu, perovskite $\mathrm{MAPbBr}_{3}$ perlu dibuat dalam bentuk kristal tunggal khususnya untuk aplikasi pada fotodetektor sinar-X, untuk menghasilkan nilai mobilitas $(\mu)$ dan lifetime $(\tau)$ muatan pembawa yang tinggi. Masalah lain dalam pembuatan kristal tunggal perovskite $\mathrm{MAPbBr}_{3}$ adalah ukuran dimensi kristal yang kecil, yaitu kurang dari $1 \mathrm{~cm}^{2}$, sehingga tidak dapat digunakan untuk aplikasi fotodetektor dalam konfigurasi flat-panel. Pada penelitian ini, dilakukan sintesis kristal perovskite $\mathrm{MAPbBr}_{3}$ menggunakan metode Inverse Temperature Crystallization (ITC). Prekursor larutan $\mathrm{MAPbBr}_{3}$ dibuat dengan variasi rasio molar $\mathrm{MABr}: \mathrm{PbBr}_{2}$ dan volume larutan prekursor. Pada metode ITC, laju kenaikan suhu divariasikan untuk mengontrol laju penumbuhan kristal. Hasil penelitian menunjukkan bahwa ukuran atau dimensi kristal yang disintesis dengan metode ITC ditentukan oleh laju kenaikan suhu. Semakin lambat laju kenaikan suhu, semakin besar ukuran kristal yang dihasilkan. Ukuran kristal $\mathrm{MAPbBr}_{3}$ terbesar yang telah berhasil dibuat dengan metode ITC adalah $8 \mathrm{~mm} \times 7 \mathrm{~mm}$ yang dibuat dengan rasio MABr: $\mathrm{PbBr}_{2}(1,25: 1)$ dengan laju kenaikan suhu $2^{\circ} \mathrm{C} / 8$ jam untuk volume larutan prekursor 3 $\mathrm{mL}$. Hasil karakterisasi XRD menunjukkan bahwa kristal perovskite $\mathrm{MAPbBr}_{3}$ berbentuk kubik dengan konstanta kisi 5,99 ̊̊. Puncak-puncak difraksi bidang kristal yang dihasilkan adalah (100), (200), (300) dan (400), yang menunjukan bahwa kristal $\mathrm{MAPbBr}_{3}$ berbentuk kristal tunggal, dengan orientasi bidang kristal dalam sumbu-x.
\end{abstract}

Kata kunci: Perovskite, $\mathrm{MAPbBr}_{3}$, metode ITC, struktur kristal, kristal tunggal

\begin{abstract}
Methylammonium lead tri-bromide $\left(\mathrm{MAPbBr}_{3}\right)$ is metal halide perovskite material that commonly used for X-ray photodetector application. However, polycrystalline crystal structure of this material causes high resistivity. Therefore, the perovskite metal halide material must be formed in a single crystal to produce low crystal defect density to increase the value of the charge carriers mobility $(\mu)$ and charge carriers lifetime $(\tau)$. Other problem in producing $\mathrm{MAPbBr}_{3}$ crystals is the low size of the single crystals less than $1 \mathrm{~cm}^{2}$, which is not suitable for flat-panel configuration of photodetector. In this research, $\mathrm{MAPbBr}_{3}$ perovskite crystals were synthesized using Inverse Temperature Crystallization (ITC) method. The precursors for the $\mathrm{MAPbBr}_{3}$ solutions were prepared by varying the molar ratio of $\mathrm{MABr}: \mathrm{PbBr}_{2}$ and the volume of the precursor solutions. In the ITC method, the rate of temperature increment was varied to control the crystal growth rate. The results showed that the size or dimension of the crystals was determined by the raising rate of temperature. The longer the temperature increment rate, the larger the crystal size was produced. The largest crystal size of $\mathrm{MAPbBr}_{3}$ that was
\end{abstract}


successfully prepared by the ITC method was $8 \mathrm{~mm} \times 7 \mathrm{~mm}$, made with the $\mathrm{MABr}: \mathrm{PbBr}_{2}$ (1.25:1) ratio with a temperature increasing rate of $2{ }^{\circ} \mathrm{C} / 8$ hours for $3 \mathrm{~mL}$ precursor solution. The XRD characterization results showed that the perovskite $\mathrm{MAPbBr}_{3}$ has cubic crustal structure with a lattice constant $5.99 \AA$. The diffraction peaks of the results crystal plane are (100), (200), (300) and (400) indicating a single crystal of $\mathrm{MAPbBr}_{3}$ is formed with crystal plane oriented in $\mathrm{x}$-axis direction.

Keywords: Perovskite, $\mathrm{MAPbBr}_{3}$, ITC method, crystal structure, single crystal

\section{Pendahuluan}

Fotodetektor energi tinggi seperti detektor sinar-X merupakan aplikasi yang sangat penting dalam bidang diagnostik medis, pengujian peralatan/komponen industri yang tidak merusak (non-destructive testing), fotodetektor neutron dan sinargamma pada pembangkit tenaga nuklir, sehingga perovskite menjadikan aspek riset yang menarik [1]. Dalam detektor sinar-X berbasis material semikonduktor, sensitivitas dan efisiensi deteksi yang tinggi merupakan parameter terpenting untuk mengurangi dosis sinar- $X$ yang diterima pasien dan pekerja selama pengukuran dan pengujian. Oleh karena itu, peningkatan efisiensi dari sensitivitas detektor sinar-X sangat penting dalam mengurangi risiko kanker dari pasien dan pekerja sekaligus untuk meningkatkan resolusi citra/image yang diperoleh.

Saat ini, detektor sinar-X berbasis semikonduktor yang banyak digunakan berbahan Silikon (Si), Selenium amorf ( $\alpha$-Se), Timbal Iodida $\left(\mathrm{PbI}_{2}\right)$, Merkuri-Iodida $\left(\mathrm{HgI}_{2}\right)$, Kadmium-Telurida (CdTe), dan Kadmium-Seng-Telurida (CdZnTe) [2]. Fotodetektor sinar-X berbahan silikon kristal tunggal walaupun memiliki perkalian mobilitas-lifetime $(\mu \tau)$, namun memiliki kendala sensitifitas yang rendah, karena koefisien absorpsi yang kecil (bilangan atom yang kecil). Sedangkan komersialisasi dan penggunaan detektor dari material $\alpha$-Se sangat terbatas, karena absorpsi pada energi tinggi dari sinar-X sangat rendah yaitu sekitar $50 \mathrm{keV}$. Sedangkan detektor berbahan $\mathrm{PbI}_{2}$ dan $\mathrm{HgI}_{2}$ memiliki masalah dengan stabilitas yang rendah terhadap lingkungan. Material CdTe dan CdZnTe memiliki prospek yang menjanjikan untuk aplikasi detektor sinar-X, namun karena mahal dan pemrosesan yang kompleks dan rumit, membatasi penggunaan material ini untuk aplikasi detektor sinar-X [2].

Dalam satu dekade terakhir, material perovskite logam-halida yang memiliki struktur kristal $\mathrm{ABX}_{3}\left(\mathrm{~A}=\mathrm{CH}_{3} \mathrm{CH}_{3}\right.$ atau $\mathrm{MA}, \mathrm{NH}_{2} \mathrm{CH}=\mathrm{NH}_{2}$ atau FA dan $\mathrm{Cs} ; \mathrm{B}=$ $\mathrm{Pb}, \mathrm{Bi}$, dan $\mathrm{Sn}$; serta $\mathrm{X}=\mathrm{I}, \mathrm{Br}, \mathrm{Cl}$ ) telah menarik banyak perhatian peneliti sebagai material pada piranti optoelektronik, seperti sel-surya, LED, Laser dan fotodetektor, karena memiliki sifat-sifat yang unggul, seperti koefisien absorpsi yang tinggi, waktu paruh rekombinasi muatan yang tinggi, panjang difusi muatan yang tinggi dan mobilitas muatan yang tinggi serta dapat disintesis dengan metode sederhana dan murah $[1,2]$.

Material perovskite dibuat dalam bentuk film tipis dan kristal tunggal untuk berbagai aplikasi piranti optoelektronik seperti sel surya, LED dan laser menggunakan berbagai teknik pembuatan berbasis larutan yang sederhana, seperti spin coating [3] dan doctor blading [4] dan teknik evaporasi vakum [5]. Melalui teknik tersebut mampu dihasilkan film perovskite polikristal dengan ukuran bulir dalam orde ratusan nanometer sampai beberapa mikrometer [6-8]. Jumlah bulir dan bidang batas bulir (grain boundaries) yang banyak dalam perovskite polikristal menurunkan sifat optoelektronik dan stabilitas material tersebut. Sebaliknya, kristal tunggal yang bebas dari batas-batas bulir menunjukan densitas cacat yang rendah, sifat optoelektronik dan stabilitas yang lebih baik dari pada film perovskite 
polikristal [9]. Simulasi yang telah dilakukan oleh Wei et al, menunjukkan bahwa diperlukan ketebalan $1 \mathrm{~mm}$ untuk $\mathrm{MAPbI}_{3}, 2 \mathrm{~mm}$ untuk $\mathrm{MAPbBr}_{3}$, sedangkan untuk Silikon diperlukan ketebalan $72 \mathrm{~mm}$ agar bisa menyetop $98 \%$ sinar-X dengan energi $50 \mathrm{keV}$ [2].

Perovskite metil-amonium timbal halida $\operatorname{MAPbX}_{3}(\mathrm{X}=\mathrm{Br}$ dan I) banyak diaplikasikan sebagai fotodetektor energi tinggi, sinar-X dan sinar- $\gamma$ [12] dan $\mathrm{MAPbCl}_{3}$ sebagai fotodetektor sinar-UV [10]. Untuk menghasilkan fotodetektor sinar-X yang ideal, material perovskite harus memiliki koefisien absorpsi yang tinggi dan energi gap yang kecil. Perovskite $\mathrm{MAPbI}_{3}$ memiliki energi gap 1,53 eV, sedangkan $\mathrm{MAPbBr}_{3} 2,24 \mathrm{eV}$, sehingga $\mathrm{MAPbI}_{3}$ lebih sesuai untuk fotodetektor sinar-X [11]. Namun stabilitas $\mathrm{MAPbI}_{3}$ terhadap lingkungan lebih rendah dibandingkan $\mathrm{MAPbBr}_{3}$, sehingga $\mathrm{MAPbBr}_{3}$ dipilih untuk material fotodetektor sinar-X. Disamping itu, $\mathrm{MAPbBr}_{3}$ memiliki struktur kubik, sehingga secara praktis lebih diinginkan untuk pembuatan fotodetektor, khususnya dalam konfigurasi panel-datar (flat-panel). Umumnya $\mathrm{MAPbI}_{3}$ yang telah berhasil disintesis menghasilkan struktur dodekahedral [12].

Fotodetektor $\mathrm{MAPbBr}_{3}$ kristal tunggal memiliki sensitivitas empat kali lebih tinggi dibandingkan detektor $\alpha$-Se [2]. Namun, masalah densitas cacat yang masih menjadi kendala dalam aplikasi detektor sinar-X berbahan perovskite secara luas. Kristal tunggal dengan ukuran besar dengan dimensi lebih dari $1 \mathrm{~cm}^{2}$ adalah sangat diperlukan untuk studi fundamental dan aplikasi fotodetektor. Kristal perovskite dengan ukuran beragam dengan ukuran kurang dari $1 \mathrm{~cm}$ telah berhasil dibuat dengan menggunakan berbagai jenis sintesis berbasis larutan seperti teknik pendinginan konvensional, kristalisasi bebatuan uap anti-pelarut (Antisolvent Vapor-Assisted Crystallization, AVC), top-seeded growth, Inverse Temperature Crystallization (ITC) dan kristalisasi pelarut acidolysis [13,14]. Namun, ukuran yang diperoleh masih relatif kecil yaitu kurang dari setengah inci, sehingga belum memenuhi kebutuhan aplikasi, khususnya untuk kepentingan praktis pembuatan fotodetektor dengan konfigurasi panel-datar (flat-panel configuration). Oleh karena itu, perlu dikembangkan metode sintesis sederhana namun dapat dikontrol untuk menghasilkan kristal tunggal perovskite dengan ukuran/dimensi lebih dari $1 \times 1 \mathrm{~cm}$ $\left(1 \mathrm{~cm}^{2}\right)$. Dalam penelitian ini dilakukan sintesis kristal perovskite $\mathrm{MAPbBr}_{3}$ menggunakan metode ITC untuk menghasilkan kristal tunggal $\mathrm{MAPbBr}_{3}$ dengan ukuran $100 \mathrm{~mm}^{2}$ atau lebih. Adapun ketebalan kristal tunggal $\mathrm{MAPbBr}_{3}$ yang diperlukan adalah minimum $2 \mathrm{~mm}$. Metode sintesis ITC digunakan karena memerlukan waktu yang lebih cepat dalam penumbuhan kristal $\mathrm{MAPbBr}_{3}$ dibandingkan dengan metode AVC. Lau penumbuhan kristal dilakukan dengan mengontrol laju kenaikan suhu dari suhu ruang sampai suhu terjadinya saturasi kristalisasi $\mathrm{MAPbBr} 3$ yaitu $80^{\circ} \mathrm{C}$.

\section{Metode Penelitian}

Pada penelitian ini, material yang digunakan adalah Pure Silicon Oil (1000 CPS), DMF (Dimethyl Formamide), bubuk Methyl Ammonium Bromide $\left(\mathrm{CH}_{3} \mathrm{NH}_{3} \mathrm{Br}\right.$ atau $\mathrm{MABr}>99 \%)$, dan bubuk timbal bromide $\left(\mathrm{PbBr}_{2} 99,999 \%\right)$. Pelarut DMF diperoleh dari Sigma Aldrich, sedangkan $\mathrm{MABr}$ dan $\mathrm{PbBr}_{2}$ dari Lumtech Inc. Taiwan.

Larutan prekursor $\mathrm{MAPbBr}_{3}$ dibuat dengan menggunakan variasi volume pelarut dan konsentrasi larutan. Pembuatan larutan dilakukan dengan mencampurkan bubuk MABr dan bubuk $\mathrm{PbBr}_{2}$, yang kemudian dilarutkan ke dalam pelarut DMF. 
Pada penelitian ini, dilakukan variasi molar $\mathrm{MABr}: \mathrm{PbBr}_{2}$ yaitu $(0,8: 1),(1: 1)$ dan (1,25:1), serta variasi DMF yaitu $1 \mathrm{~mL}, 2 \mathrm{~mL}$ dan $3 \mathrm{~mL}$. Selanjutnya larutan diaduk menggunakan stirrer di atas hot-plate pada suhu ruang dengan kecepatan $300 \mathrm{rpm}$ selama 60 menit sehingga diperoleh larutan yang homogen. Pada salah satu variasi percobaan, larutan difilter dengan filter 0,45 microsyringe untuk menghilangkan partikel yang tidak larut. Larutan prekursor yang telah homogen selanjutnya dilakukan penumbuhan kristal dengan metode ITC. Pertama, larutan perovskite yang telah homogen dimasukkan ke dalam botol vial $5 \mathrm{~mL}$, dan kemudian dimasukan ke dalam gelas kimia $50 \mathrm{~mL}$ yang berisi $28 \mathrm{ml}$ cairan silicon oil. Selanjutnya diletakkan di atas mantle heater dan dilakukan variasi laju kenaikan suhu. Kenaikan suhu yang dilakukan mulai dari suhu $30^{\circ} \mathrm{C}$ sampai $80^{\circ} \mathrm{C}$ dengan berbagai variasi kenaikan suhu. Pada saat suhu antara $50^{\circ} \mathrm{C}$ sampai $76^{\circ} \mathrm{C}$, benih kristal mulai terbentuk dan kemudian kristal membesar seiring dinaikannya suhu dan lama waktunya. Ukuran kristal yang dihasilkan bergantung pada laju kenaikan suhu sintesis. Pola XRD pada kristal $\mathrm{MAPbBr}_{3}$ dihasilkan melalui pengukuran XRD yang dilakukan menggunakan $X$-ray Diffraction Bruker D8 Advance $3 \mathrm{~kW}$ dengan detektor LynxEye $X E-T$ dan sumber radiasi $\mathrm{Cu}-\mathrm{K} \alpha$ dengan panjang gelombang $1,54 \AA$.

\section{Hasil dan Pembahasan}

Ukuran kristal perovskite $\mathrm{MAPbBr}_{3}$ yang telah disintesis dengan metode ITC diukur dalam dimensi panjang $\times$ lebar $(\mathrm{mm} \times \mathrm{mm})$. Semua kristal yang dihasilkan memiliki tebal antara 2-3 mm, sehingga memenuhi syarat menyetop $98 \%$ sinar-X dengan energi $50 \mathrm{keV}$ [2]. Larutan perovskite $\mathrm{MAPbBr}_{3}$ dengan variasi konsentrasi molaritas $\mathrm{MABr}: \mathrm{PbBr}_{2}$ dan variasi laju kenaikan suhu menghasilkan kristal-kristal dengan berbagai ukuran. Gambar 1 memperlihatkan contoh foto kristal $\mathrm{MAPbBr}_{3}$ yang dihasilkan pada laju kenaikan suhu $2^{\circ} \mathrm{C} /$ jam untuk rasio molar $\mathrm{MABr}: \mathrm{PbBr}_{2}$ 1:1 dan 1,25:1. Dimensi kristal yang berbeda tampak untuk kristal yang disintesis dengan perbandingan molar $\mathrm{MABr}: \mathrm{PbBr}_{2}$ dan kenaikan suhu $2^{\circ} \mathrm{C}$ setiap 4 jam dan setiap 6 jam dari suhu $30^{\circ} \mathrm{C}$ sampai $70^{\circ} \mathrm{C}$. Namun dimensi panjang dan lebarnya sama yaitu $4 \mathrm{~mm} \times 4 \mathrm{~mm}$ untuk sampel yang disintesis dengan kenaikan suhu $2^{\circ} \mathrm{C} / 8$ jam [Gambar 1(b)].

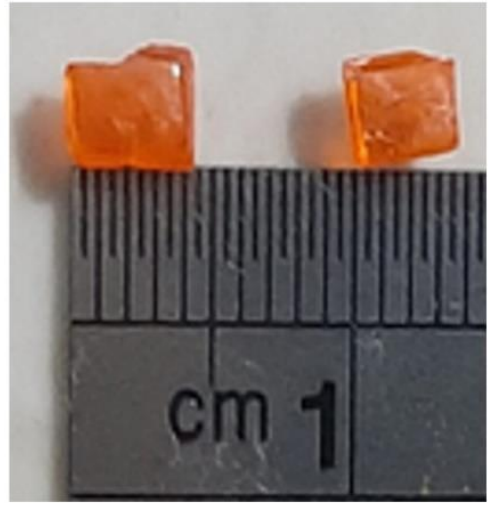

(a)

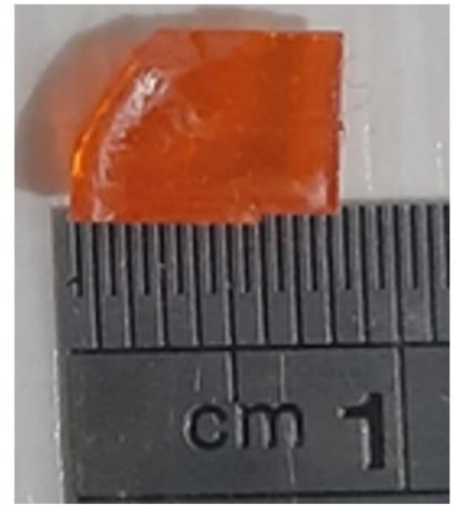

(b)

Gambar 1. Foto kristal $\mathrm{MAPbBr}_{3}$ yang dihasilkan pada laju kenaikan suhu $2{ }^{\circ} \mathrm{C} / \mathrm{jam}$ untuk rasio molar $\mathrm{MABr}: \mathrm{PbBr}_{2}$ 1:1 dan 1,25:1 
Dimensi atau ukuran kristal yang disintesis dengan metode ITC secara lengkap disajikan pada Tabel 1. Ukuran kristal semakin besar jika rasio $\mathrm{MABr}: \mathrm{PbBr}_{2}$ meningkat dan volume larutan prekursor perovskite dinaikkan dari $2 \mathrm{~mL}$ menjadi 3 mL. Namun bentuk kristal tidak persegi, melainkan memiliki lengkungan di salah satu sisinya, yang mungkin disebabkan oleh sulitnya mengontrol laju kenaikan suhu yang rendah secara presisi. Dalam beberapa kasus, terbentuknya kristal terjadi di pinggir botol bahkan menempel, sehingga pertumbuhan kristal tidak merata. Oleh karena itu, kontrol kenaikan suhu merupakan parameter yang penting dalam metode ITC untuk menghasilkan kristal perovskite $\mathrm{MAPbBr}_{3}$ dengan bentuk persegi (ukuran dimensi panjang dan lebar yang sama). Kenaikan laju suhu dalam sintesis $\mathrm{MAPbBr}_{3}$ dengan metode ITC, umumnya dilakukan dengan sangat lambat yaitu 1$2{ }^{\circ} \mathrm{C}$ /hari untuk menghasilkan kristal perovskite $\mathrm{MAPbBr}_{3}$ yang persegi dengan ukuran kristal lebih dari $1 \mathrm{~cm}^{2}[15,16]$.

Tabel 1. Dimensi ukuran kristal $\mathrm{MAPbBr}_{3}$ yang disintesis dengan metode ITC

\begin{tabular}{|c|c|c|c|c|c|}
\hline No. & $\operatorname{MABr}(\mathrm{M})$ & $\mathrm{PbBr}_{2}(\mathrm{M})$ & $\begin{array}{l}\text { Volume } \\
\text { (ml) }\end{array}$ & $\begin{array}{l}\text { Laju kenaikan } \\
\text { Suhu }\end{array}$ & $\begin{array}{l}\text { Ukuran kristal } \\
\qquad\left(\mathrm{mm}^{2}\right)\end{array}$ \\
\hline 1 & 0,8 & 1 & 2 & $22^{\circ} \mathrm{C} / 6$ jam & $3 \times 3$ \\
\hline 2 & 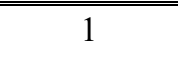 & 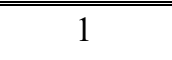 & 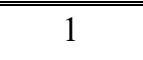 & 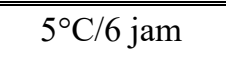 & $5 \times 5$ \\
\hline 3 & 1 & 1 & 2 & $2^{\circ} \mathrm{C} / 4 \mathrm{jam}$ & $8 \times 3$ \\
\hline 4 & 1 & 1 & 2 (filter) & $2^{\circ} \mathrm{C} / 4 \mathrm{jam}$ & $4 \times 3$ \\
\hline 5 & 1 & 1 & 2 & $2^{\circ} \mathrm{C} / 6$ jam & $5 \times 3$ \\
\hline 6 & 1 & 1 & 2 & $2^{\circ} \mathrm{C} / 8 \mathrm{jam}$ & $4 \times 4$ \\
\hline 7 & 1 & 1 & 3 & $2^{\circ} \mathrm{C} / 4$ jam & $6 \times 3$ \\
\hline 8 & 1,25 & 1 & 3 & $2^{\circ} \mathrm{C} / 4 \mathrm{jam}$ & $6 \times 5$ \\
\hline 9 & 1,25 & 1 & 3 & $2^{\circ} \mathrm{C} / 8 \mathrm{jam}$ & $8 \times 7$ \\
\hline
\end{tabular}

Gambar 2 memperlihatkan hubungan antara luas $(\mathrm{A}=$ panjang $\times$ lebar $)$ dari kristal $\mathrm{MAPbBr} 3$ yang dihasilkan sebagai fungsi dari rasio $\mathrm{MABr}: \mathrm{PbBr}_{2}$ untuk variasi laju kenaikan suhu. Tampak bahwa laju kenaikan suhu sangat menentukan ukuran kristal yang terbentuk. Ukuran kristal dengan dimensi $1 \mathrm{~cm}^{2}$ belum berhasil disintesis dengan metode ITC. Diperlukan kenaikan suhu yang lambat dengan kontrol suhu yang presisi untuk menghasilkan kristal dengan dimensi yang besar. Liu et al menggunakan kombinasi metode ITC dengan metode Low-Temperature Gradient Crystallization (LTGC) untuk membuat kristal $\mathrm{MAPbBr}_{3}$ dengan ukuran yang besar. Larutan prekursor didalam botol tertutup dipanaskan secara perlahan yaitu $2^{\circ} \mathrm{C} /$ hari. Ukuran kristal yang terbentuk memiliki dimensi $44 \mathrm{~mm} \times 49 \mathrm{~mm} \times$ $17 \mathrm{~mm}$ setelah waktu penumbuhan kristal selama 18 hari $[15,16]$. 


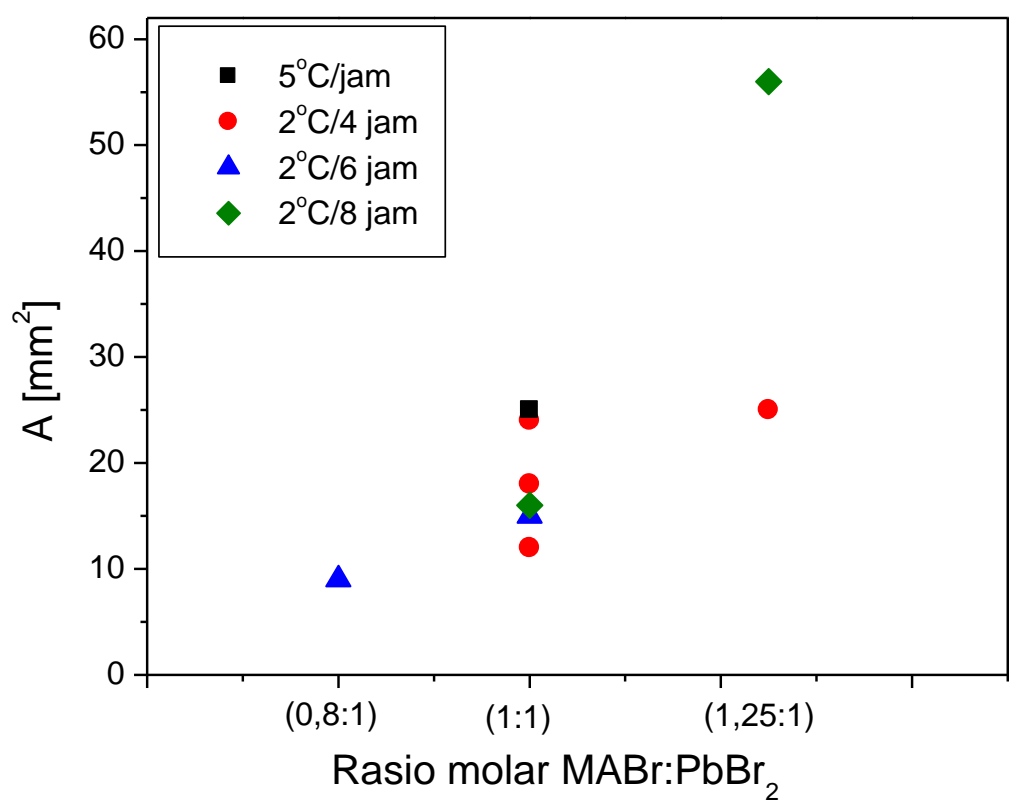

Gambar 2. Hubungan antara luas kristal $\mathrm{MAPbBr}_{3}$ dengan rasio molar $\mathrm{MABr}: \mathrm{PbBr}_{2}$ untuk variasi laju kenaikan suhu

Gambar 3 memperlihatkan pola XRD dari sampel kristal $\mathrm{MAPbBr}_{3}$ yang dibubukkan. Pola XRD hasil simulasi untuk kristal $\mathrm{MAPbBr}_{3}$ berbentuk kubik dengan konstanta kisi 5,99 Å juga diperlihatkan pada Gambar 3. Puncak-puncak difraksi menunjukkan arah bidang bidang kristal yang terorientasi ke arah sumbu$\mathrm{x}$, sumbu-xy dan sumbu-xyz. Hal ini karena sampel kristal sebelumnya dibubukkan sehingga sampel berbentuk bubuk. Akibatnya pada proses pengujian XRD, sinar-X akan terhambur ke beberapa arah, yang menghasilkan polikristal. Pola XRD dari sampel memiliki puncak-puncak difraksi pada sudut yang sama dengan hasil simulasi struktur kristal $\mathrm{MAPbBr}_{3}$ yang berbentuk kubik dengan konstanta kisi 5,99 $\AA$ [17]. Hal ini menunjukkan bahwa sampel memiliki struktur kubik dengan dengan konstanta kisi a $=5,99 \AA$. Namun puncak difraksi bidang kristal (111) pada sudut $26,4^{\circ}$ pada sampel hasil eksperimen tidak muncul. Hal ini mungkin karena bentuk kristalnya persegi, sehingga kristal cenderung terorientasi dalam arah sumbu-x atau sumbu-y atau bisang $\mathrm{x}-\mathrm{y}$.

Pola XRD dari sampel kristal $\mathrm{MAPbBr}_{3}$ yang memiliki dimensi ukuran yang besar yaitu $8 \mathrm{~mm} \times 7 \mathrm{~mm}$ diperlihatkan pada Gambar 4 (a). Pola XRD memperlihatkan puncak-puncak difraksi bidang kristal (100), (200), (300) dan (400). Pola XRD untuk ukuran kristal yang lain menunjukkan puncak-puncak difraksi yang sama, hanya nilai intensitasnya yang berbeda, seperti diperlihatkan pada pola XRD untuk ukuran kristal $6 \mathrm{~mm} \times 4 \mathrm{~mm}$ [Gambar 4(b)]. Pola XRD yang dihasilkan tidak bergantung pada ukuran kristal $\mathrm{MAPbBr}_{3}$ yang dihasilkan. Hasil XRD ini menunjukkan bahwa kristal $\mathrm{MAPbBr}_{3}$ berbentuk kristal tunggal telah berhasil disintesis dengan metode ITC dengan arah orientasi bidang kristal sejajar sumbu-X. 


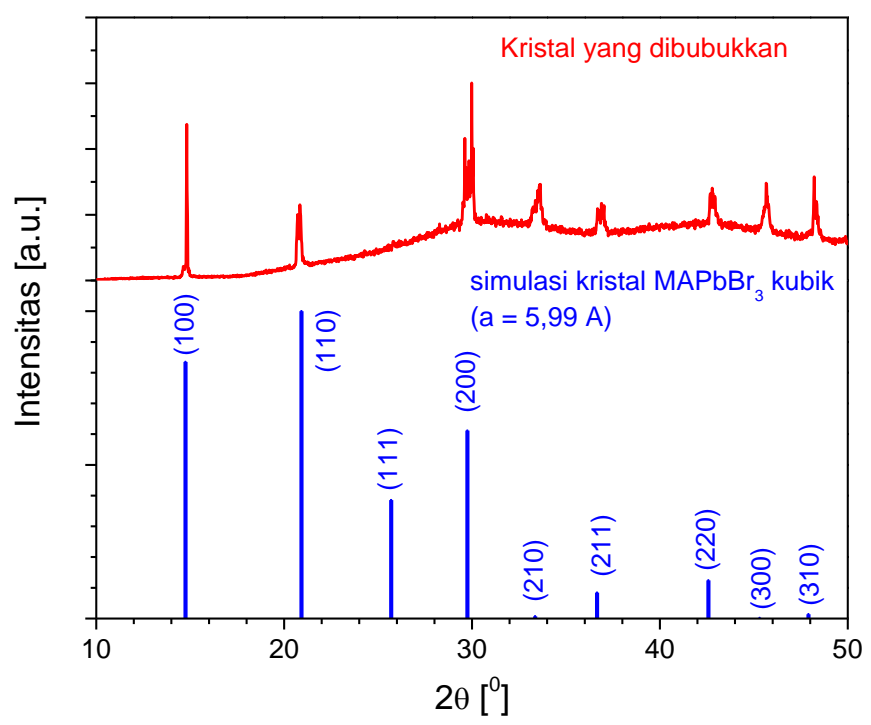

Gambar 3. Pola XRD kristal perovskite $\mathrm{MAPbBr}_{3}$ yang disintesis dengan metode ITC yang dibubukkan dan Pola XRD hasil simulasi untuk kristal $\mathrm{MAPbBr}_{3}$ berbentuk kubik dengan konstanta kisi 5,99 ̊
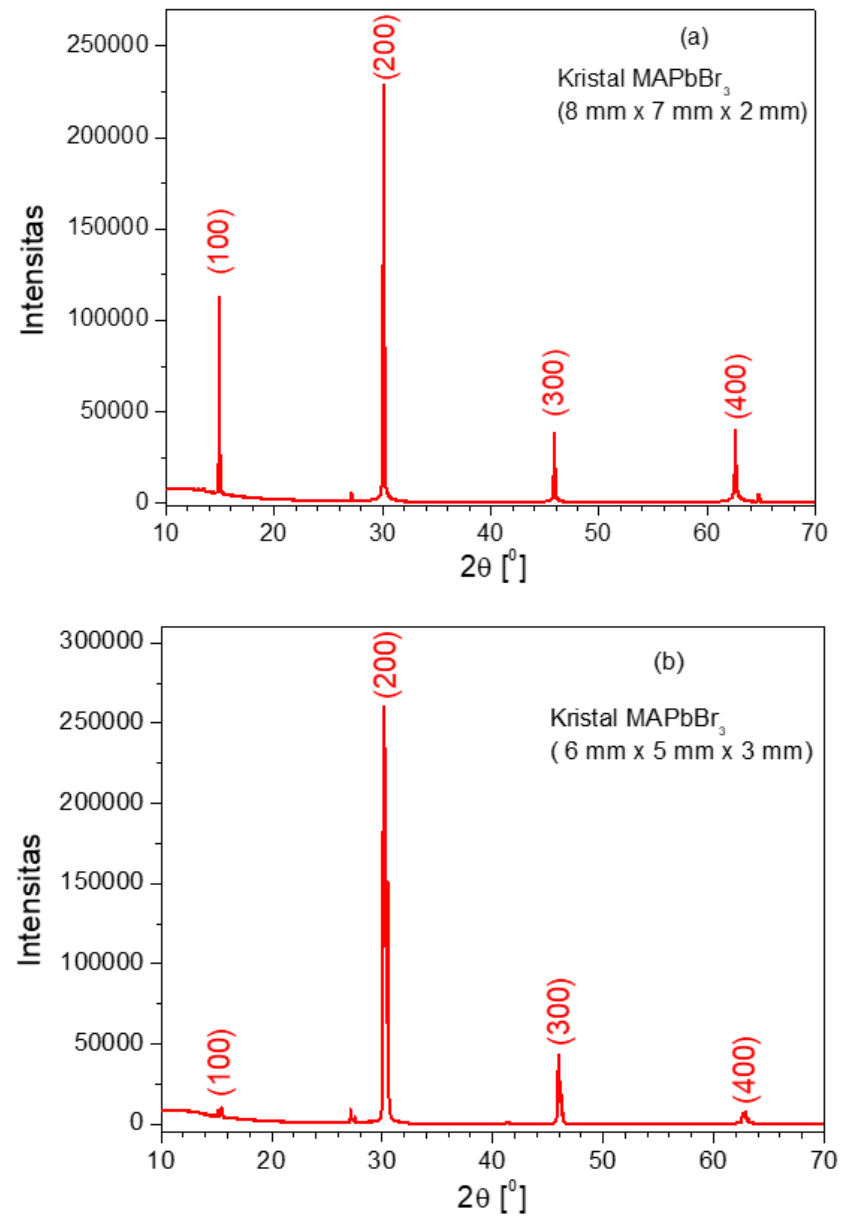

Gambar 4. Pola XRD kristal perovskite $\mathrm{MAPbBr}_{3}$ yang memiliki ukuran (a). $8 \mathrm{~mm}$ x $7 \mathrm{~mm}$, dan (b). $6 \mathrm{~mm}$ x $6 \mathrm{~mm}$ 


\section{Kesimpulan}

Kristal perovskite $\mathrm{MAPbBr}_{3}$ telah berhasil dibuat dengan metode Inverse Temperature Crystallization (ITC). Penumbuhan kristal perovskite $\mathrm{MAPbBr}_{3}$ dengan metode ITC dipengaruhi oleh laju kenaikan suhu. Semakin lambat laju kenaikan suhu, semakin besar ukuran kristal $\mathrm{MAPbBr}_{3}$ yang dihasilkan. Kristal dengan dimensi terbesar yang telah berhasil dibuat memiliki ukuran $8 \mathrm{~mm} \times 7 \mathrm{~mm}$ yang diperoleh untuk rasio molar $\mathrm{MABr}: \mathrm{PbBr}_{2}(1,25: 1)$ dengan laju kenaikan suhu $2^{\circ} \mathrm{C} / 8$ jam. Hasil pengujian XRD menunjukan bahwa kristal perovskite $\mathrm{MAPbBr}_{3}$ berbentuk kristal tunggal dengan arah orientasi bidang kristal sejajar dengan sumbu-X.

\section{Ucapan Terima Kasih}

Penelitian ini didukung oleh Hibah Riset Universitas Padjadjaran (HRU), Riset Kompetensi Dosen Unpad (RKDU), Nomor kontrak 1959/UN6.3.1/PT.00/2021, tanggal 22 April 2021.

\section{Daftar Pustaka}

1. H. Zhang, F. Wang, Y. Lu, Q. Sun, Y. Xu, B.-B. Zhang, W. Jie and M. G. Kanatzidis, "High-sensitivity $\mathrm{X}$-ray detectors based on solution-grown caesium lead bromide single crystals", J. Mater. Chem. C Vol. 8 (2020), 1248-1256.

2. H. Wei, Y. Fang, P. Mulligan, W. Chuirazzi, H.-H. Fang, C. Wang, B. R. Ecker, Y. Gao, M. A. Loi, L. Cao and J. Huang, "Sensitive X-ray detectors made of methylammonium lead tribromide perovskite single crystals", Nat. Photon. Vol. 10 (2016), 333-340.

3. Q. Wang, X. Zeng, Y. Deng, J. Zhao, Z. Chen and J. Huang, "Stabilizing the $\alpha$-phase of $\mathrm{CsPbI}_{3}$ perovskite by sulfobetaine zwitterions in one-step spin coating films", Joule Vol. 1 (2017), 371-382.

4. Q. Hu, H. Wu, J. Sun, D. Yan, Y. Gao and J. Yang, ,Large-area perovskite nanowire arrays fabricated by large-scale roll-to-roll micro-gravure printing and doctor blading", Nanoscale Vol. 8 (2016), 5350-5357.

5. C.-W. Chen, H.-W. Kang, S.-Y. Hsiao, P.-F. Yang, K.-M. Chiang and H.-W. Lin, "Efficient and uniform planar-type perovskite solar cells by simple sequential vacuum deposition", Adv. Mater. Vol. 26 (2014), 6647-6652.

6. Q. Jiang, Y. Zhao, X. Zhang, X. Yang, Y. Chen, Z. Chu, Q. Ye, X. Li, Z. Yin and J. You, "Surface passivation of perovskite film for efficient solar cells", Nat. Photon. Vol. 13 (2019), 460-466.

7. Y. Bai, Y. Lin, L. Ren, X. Shi, E.a Strounina, Y. Deng, Q. Wang, Y. Fang, X. Zheng, Y. Lin, Z.-G. Chen, Y. Du, L. Wang and J. Huang, "Oligomeric silicawrapped perovskites enable synchronous defect passivation and grain stabilization for efficient and stable perovskite photovoltaics", ACS Energy Lett. Vol. 4 (2019), 1231-1240.

8. X. Cheng, S. Yang, B. Cao, X. Tao and Z. Chen, "Single crystal perovskite solar cells: Development and perspectives", Adv. Funct. Mater. Vol 30 (2020), 1905021 (20 Halaman). 
9. J. Ding, S. Du, T. Zhou, Y. Yuan, X. Cheng, L. Jing, Q. Yao, J. Zhang, Q. He, H. Cui, X. Zhan and H. Sun, "Cesium decreases defect density and enhances optoelectronic properties of mixed $\mathrm{MA}_{1-\mathrm{X}} \mathrm{Cs}_{\mathrm{X}} \mathrm{PbBr}_{3}$ single crystal", J. Phys. Chem C Vol. 123 (2019), 14969-14975.

10. G. Maculan, A. D. Sheikh, A. L. Abdelhady, M. I. Saidaminov, M. A. Haque, B. Murali, E. Alarousu, O. F. Mohammed, T. Wu and O. M. Bakr, " $\mathrm{CH}_{3} \mathrm{NH}_{3} \mathrm{PbCl}_{3}$ single crystals: Inverse temperature crystallization and visible-blind UV-photodetector", J. Phys. Chem. Lett. Vol. 6 (2015), 37813786.

11. Y. Liu, Z. Yang, D. Cui, X. ren, J. Sun, X. Liu, J. Zhang, Wei, H. fan, F. Yu, C. Zhao and S. Lie, "Two-inch-sized perovskite $\mathrm{CH}_{3} \mathrm{NH}_{3} \mathrm{PbX}_{3}(\mathrm{X}=\mathrm{Cl}, \mathrm{Br}, \mathrm{I})$ crystals: Growth and characterization", Adv. Mater. Vol. 27 (2015), 5176-5183.

12. Y. Su, W. Ma and Y. Yang, "Perovskite semiconductors for direct X-ray detection and imaging", J. Semicond. Vol. 41 (2020), 051204 (10 Halaman).

13. S. Arya, P. Mahajan, R. Gupta, R. Srivastava, N. K. Tailor, S. Satapathi, R. R. Sumathi, R. Datt and V. Gupta, "A comprehensive review on synthesis and applications of single crystal perovskite halides", Prog. Solid State Chem. Vol. 60 (2020), 100286 (35 Halaman).

14. S. -S. Rong, M. B. faheem and Y.-B. Li, "Perovskite single crystals:Synthesis, properties and applications", J. Electron. Sci. Technol. (2021), 100081 (18 Halaman)

15. Y. Liu, Y. Zhang, Z. Yang, J. Fang, Z. Xu, Q. Li, M. Hu, H. Ye, X. Zhang, M. Liu, K. Zhao and S. Liu, "Low-temperature-gradient crystallization for multiinch high-quality perovskite single crystals for record performance photodetectors", Mater. Today Vo. 22 (2018), 67-75.

16. Y.-C. Liu, Y.-X. Zhang, K. Zhao, Z. Yang, J. Feng, X. Zhang, K. Wang, L. Meng, H. Ye, M. Liu and S. Liu, "A $1300 \mathrm{~mm}^{2}$ ultrahigh-performance digital imaging assembly using high-quality perovskite single crystals", Adv. Mater. Vol. 30 (2018), 1707314 (11 Halaman).

17. R. M. Muslimawati, Setianto, M. Manawan and A. Bahtiar, "Synthesis of single crystal perovskite $\mathrm{MAPbBr}_{3}$ by using anti-solvent vapor-assisted crystallization method for X-ray photodetector application", Journal of Physics: Conference Series (2021), submitted 